\title{
PARONYCHIA VIRGINICA (CARYOPHYLLACEAE), A FIRST REPORT OF ITS OCCURRENCE IN MEXICO
}

\author{
B.L. Turner \\ Department of Botany, University of Texas, Austin, Texas 78713 U.S.A.
}

\begin{abstract}
Paronychia virginica Spreng. is widespread in the eastern U.S.A. but has not previously been reported for México, although it is relatively common in central Texas. Recent collections by D.H. Riskind from the Serranias del Burro, Mpio. Villa Acuña, Coahuila, México has extended its distribution about 300 kilometers southwestwards from its previously known range. A map showing its distributions in Texas and México is provided.
\end{abstract}

KEY WORDS: Caryophyllaceae, Paronychia, Texas, México

Routine identification of plants from northern México has revealed the occurrence of Paronychia virginica Spreng. in México, where it has not heretofore been reported. All of the collections ( 3 sheets) were made by Mr. David H. Riskind, in the Serranias del Burro, Mpio. de Villa Acuña, Rancho el Bonito (ca. $29^{\circ} 01^{\prime} 30^{\prime \prime} \mathrm{N}, 102^{\circ} 07^{\prime} 30^{\prime \prime}$ W), as follows:

1. Canyon El Toro, 18 Sep 1977, R. 2142 (TEX).

2. Head of Canyon El Bonito, plateau of open pine-oak woodland, 2300 m, 20 Sep 1977, R. 2263 (TEX).

3. Open slope between canyons El Bonito and Pantera, 20 Sep 1977, R. 2286 (TEX).

Figure 1 shows the distribution of Paronychia virginica in Texas and México. This is based upon collections from Texas as reported in Turner (1983. Phytologia 54:9-23.) and upon collections assembled at LL, TEX since that time. 


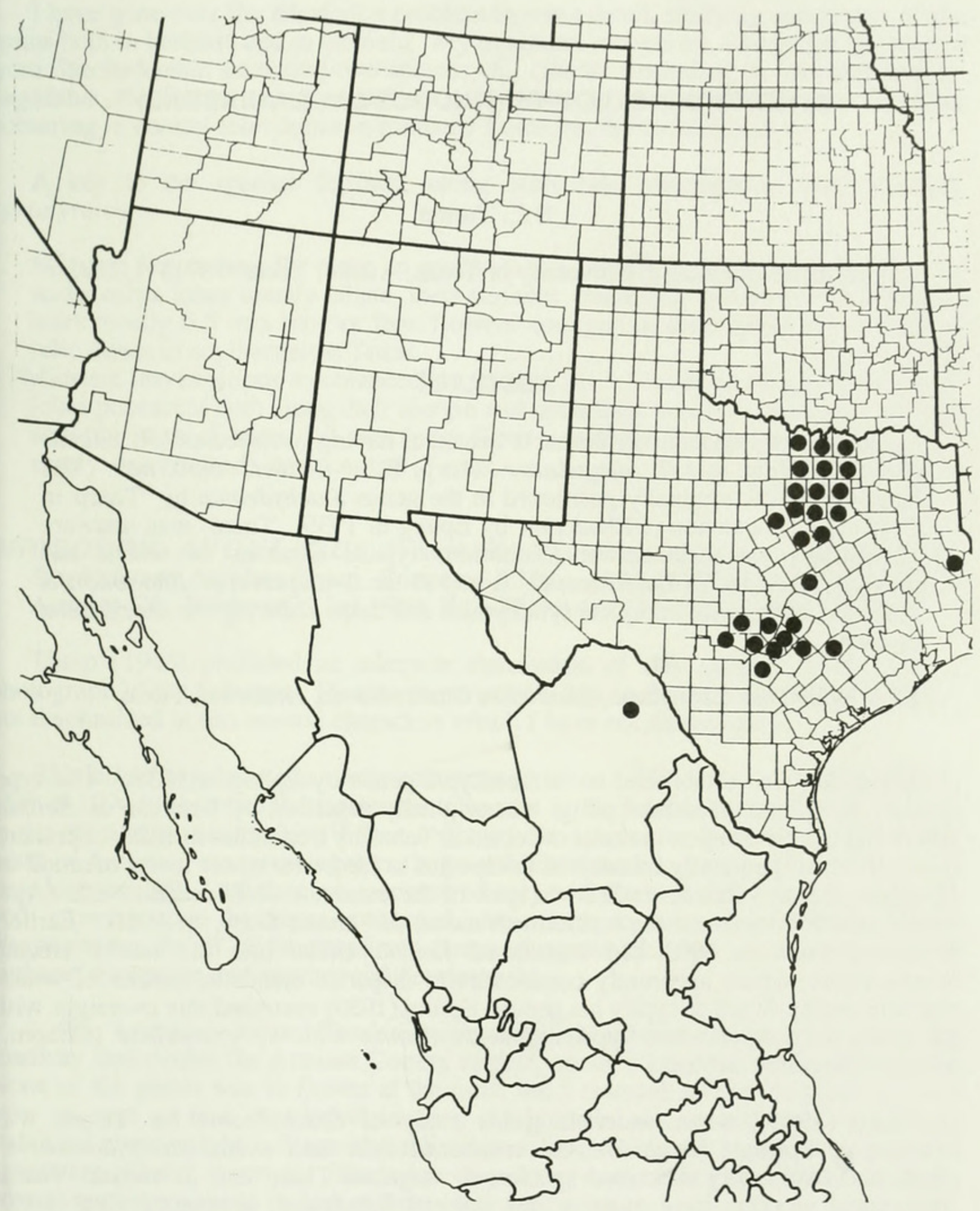

Fig. 1. Distribution of Paronychia virginica in Texas and Mexico. 


\section{$2 \mathrm{BHL}$ Biodiversity Heritage Library}

Turner, B. L. 1995. "Paronychia virginica (Caryophyllaceae), a first report of its occurrence in Mexico." Phytologia 78, 446-447.

https://doi.org/10.5962/bhl.part.29685.

View This Item Online: $\underline{\text { https://www.biodiversitylibrary.org/item/46874 }}$

DOI: https://doi.org/10.5962/bhl.part.29685

Permalink: https://www.biodiversitylibrary.org/partpdf/29685

\section{Holding Institution}

New York Botanical Garden, LuEsther T. Mertz Library

\section{Sponsored by}

The LuEsther T Mertz Library, the New York Botanical Garden

\section{Copyright \& Reuse}

Copyright Status: In copyright. Digitized with the permission of the rights holder.

Rights Holder: Phytologia

License: http://creativecommons.org/licenses/by-nc-sa/3.0/

Rights: https://biodiversitylibrary.org/permissions

This document was created from content at the Biodiversity Heritage Library, the world's largest open access digital library for biodiversity literature and archives. Visit BHL at https://www.biodiversitylibrary.org. 